\title{
POLLINATION ECOLOGY OF INDIAN TULIP TREE, THESPESIA POPULNEA (L.) SOL. EX CORREA (MALVACEAE), A VALUABLE EVERGREEN TREE SPECIES FOR COASTAL ECORESTORATION
}

\author{
Jacob Solomon Raju ALURI *, Venkata Ramana KUNUKU **, \\ Prasada Rao CHAPPIDI ***, Bhushanam Jeevan Prasad KAMMARCHEDU ****, \\ Sravan Kumar SAMAREDDY *****, Suneetha Rani TRIPURANA ******, \\ Santhi Kumari MANJETI ******* and Divyasree MOCHARLA ********
}

$*$, ****, *****, ******, *******, ********, Andhra University, Department of Environmental Sciences, Visakhapatnam, India, IN-530003, solomonraju@gmail.com, kbjpamith@gmail.com, sravankumarsamareddy@gmail.com,sunita.gandham@gmail.com

**, *** Andhra University, Department of Botany, Visakhapatnam, India, IN-530003, ramanabtny@gmail.com, prasadachram@gmail.com

DOI: 10.2478/trser-2020-0016

KEYWORDS: Hermaphroditism, self-compatibility, melittophily, floral biology, pollinators, fruiting, seed dispersal.

\section{ABSTRACT}

Thespesia populnea is a coastal evergreen tree species which flowers seasonally. The flowers are hermaphroditic, self-compatible, self-pollinating, and principally melittophilous. The fruits are indehiscent, turban-shaped, capsules, which release seeds in tidal water upon the decay of their pericarp. Both fruits and seeds are buoyant and typically hydrochorous. This species is a source of wood, dye, food, traditional medicine, being also used as an ornamental and avenue tree. Therefore, it is important in coastal eco-restoration and carbon sequestration.

ZUSAMMENFASSUNG: Bestäubungsökologie des Indischen Tulpenbaums Thespesia populnea (L.) Sol. ex Correa (Malvaceae), eine wertvolle immergrüne Art für die ökologische Küstenrenaturierung.

Thespesia populnea ist eine immergrüne Baumart der Küstenzone, die Saison bedingt blüht. Die Blüten sind zwegeschlechtig, selbstverträglich, selbstbestäubend und hauptsächlich melittophil. Die Früchte sind nicht aufspringende, turbanförmige Kapseln, die beim Zerfall ihres Perikarps Samen ins Gezeitenwasser freisetzen. Sowohl die Früchte als auch die Samen sind schwimmfähig und typischerweise hydrochor. Diese Art stellt eine Quelle für Holz, Farbstoffe, Nahrung, und traditionelle Medizin dar. Sie wird auch als Zier- und Alleebnaum verwendet. Daher ist sie für die ökologische Renaturierung der Küste und Kohlenstoffspeicherung von Bedeutung.

REZUMAT: Ecologia polenizării la arborele indian de lalea Thespesia populnea (L.) Sol. ex Correa (Malvaceae), o valoroasă specie sempervirescentă pentru refacerea ecologică a zonelor costiere.

Thespesia populnea este o specie perenă de arbore, care înflorește sezonier. Florile sunt hermafrodite, auto-compatibile, auto-polenizante și preponderent melitofile. Fructele formează capsule indehiscente sub formă de turban, care eliberează semințele în apa mareelor în urma degradării pericarpului lor. Atât fructele, cât și semințele sunt flotante și de obicei hidrochore. Această specie constituie o sursă de lemn, vopsea, alimente, medicamente tradiționale având importanță și ca arbore ornamental folosit și de-a lungul bulevardelor. Datorită acestui fapt arborele indian de lalea este important în restaurarea ecologică a zonelor coastiere maritime și în sechestrarea carbonului. 


\section{INTRODUCTION}

Trees are an important part of the terrestrial ecosystems. Leaves, flowers, and fruits are seasonally available. On the ground underneath the trees, there is shade, undergrowth, leaf litter, fallen branches and decaying wood that provide other habitats. The trees stabilize the soil, averts rapid run-off of rain water, while also helping prevent desertification, and has a role in climate control and helps toward the maintenance of biodiversity and the ecosystem's balance (Lowman, 2009). The riverine ligneous vegetation is important for aquatic ecosystems status (Curtean-Bănăduc et al., 2014). Evergreen species exhibit different ecological strategies to cope with different climates (van Ommen Kloeke et al., 2012). Long-lived leaves of evergreen species potentially allow for a longer photosynthetic season than the leaves of deciduous species (González-Zurdo et al., 2016). Therefore, trees in general, along with evergreen tree species in particular, that have long lives and are bearing leaves throughout the year, are important in maintaining the biological and ecological aspects of the concerned ecosystems where trees are the main constituents.

The genus Thespesia Sol. ex Correa belongs to Malvaceae family. It consists of 16 different species of trees and shrubs distributed in Southeast Asia-Oceania, Chandigarh in India and America (Troup, 1921). The name "thespesia" is derived from the Greek word "thespesios", which means divine or sacred (Friday and Okano, 2006). The members of genus Thespesia are valued for their multiple uses; such as medicine, food, dye, timber, fibre, and ornamental aspect (Friday and Okano, 2006). Among these species, T. populnea is the most well-known typical coastal tree species of the tropical coasts (Areces-Berazain and Ackerman, 2016). It has a very broad native range and is widely distributed throughout the tropics, it's presence being most common in the coastal areas of Central America, northern South America, the Caribbean, Africa, Asia, northern Australia, and on Indian and Pacific Ocean islands (Little and Skolmen, 1989; Oudhia, 2007; USDA-ARS, 2015). It is cultivated occasionally in Central and South America (Francis, 2004). In India, it is a common species in the coastal tracts of the Indian Peninsula and in mangrove swamps. It is often developed as an avenue tree in cities and towns near sea coast (Troup, 1921). It is an important tree in the culture and religious practises of many countries of the Indo-Pacific region. In ancient times, the species of this genus were planted around the places of worship in Tahiti of French Polynesia (Fosberg and Sachet, 1972; Friday and Okano, 2006). Further, this tree species is used as an important source of wood for making boats and furniture because of its durability when continually exposed to water or ground, as well as termite-resistance (Little and Skolmen, 1989; Oudhia, 2007). Its flowers and young leaves are edible and are included in the list of species used as famine food. It's fibrous bark is used for curing leather while the fruit extract is used as a natural dye. Apart from these values, all plant parts are used in traditional medicine (Oudhia, 2007).

Despite the wide distribution and multiple uses of $T$. populnea, limited data is available on its pollination ecology, which is essential for its cultivation and use. Gandhi (2000) reported that this species is pollinated by sunbirds in India while Oudhia (2007) said that is likely to be pollinated by birds in Africa. Woodell (1979) noted that T. populnea is visited by the carpenter bee, Xylocopa calens Lepeletier 1841 on Aldabra Islands in the Indian Ocean. Singh and Kar (2011) based on melissopalynological study reported that the honey bees affect pollination in the Sunderbans of Bangladesh and Little Andamans of India. Shanmugapriya and Vanitharani (2015) noted that this species is pollinated by 14 species of lepidopterans in the Mandapam islands of India. These reports indicate that there is a lacuna of data on the pollination ecology of $T$. populnea. This study provides the details of floral biology, pollinators, fruiting and seed dispersal aspects of this species (Fig. 1a), to help understand it's sexual reproduction and regeneration for use in coastal eco-restoration. 


\section{MATERIAL AND METHODS}

Thespesia populnea trees growing along the $135 \mathrm{~km}$ long coastline in Visakhapatnam

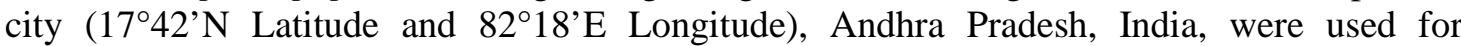
this study during January 2018 - November 2019. Regular visits to the location of the trees were made to make field observations on flowering, floral biology, pollinators, fruiting, and seed dispersal. Fifteen mature buds about to anthesis on five plants spatially separated were tagged and followed to note anthesis and anther dehiscence schedules. The timing of anther dehiscence was confirmed by observing the anthers under a 10x hand lens. Fifteen fresh flowers from the same trees were collected and observed to record the flower type, sex, shape, colour, calyx, corolla, stamens, ovary, style and stigma. The floral morphology, nectar and pollen rewards presentation were observed in relation to the probing and forage collection activities of insects. Twenty mature buds comprising two buds each from ten plants were bagged and then tagged to measure nectar volume and sugar concentration. The nectar volume was collected by inserting a micropipette into the corolla base. The average nectar of ten flowers from five trees was taken as the total volume of nectar/flower and expressed in $\mu \mathrm{L}$. Hand Sugar Refractometer (Erma, Japan) was used for recording nectar sugar concentration. The stigma receptivity was observed visually. Insects visiting the flowers for forage collection were observed all day-long on four different days using binoculars for their mode of approach, landing, probing behaviour and contact with the floral sexual organs; they were identified by tallying them with the specimens already identified by the Zoological Society of India, Calcutta, India and available in the Department of Andhra University, Visakhapatnam. The foraging visits made by each insect species were recorded for ten minutes every hour from 06:00 to 18:00 h. The data was used to record the foraging activity schedule in relation to the availability of flowers and to examine the pattern of foraging activity with the passage of time from morning to evening. The fruit maturation period, fruit and seed characteristics, fruit and seed dispersal aspects were observed by making field visits at four-day intervals during March-May for fruit development and maturation.

\section{RESULTS \\ Floral Biology}

Flowering occurs during November-March but shows sporadic flowering outside this period. Flowers are solitary with four-five $\mathrm{cm}$ long pedicel and borne in leaf axils mostly of terminal branches. They are bright yellow, bell-shaped, $5.8 \pm 0.56 \mathrm{~cm}$ long with overlapping broad and rounded petals. The calyx is cupular with five minute teeth, green and accrescent. The corolla consists of five bright yellow glabrous broad $6.1 \pm 0.23$ $\mathrm{cm}$ long and $4.7 \pm 0.7 \mathrm{~cm}$ wide petals and each petal has a maroon or purple coloured spot at its base representing nectar guide. The petals are shortly fused at base but twisted and free above. The androecium is composed of $2.5 \pm 0.2 \mathrm{~cm}$ long staminal tube with numerous stamens (Fig. 1i); each stamens has $0.3 \pm 0.01 \mathrm{~cm}$ long ascending filament and terminated with a reniform anther. The gynoecium has a five-carpelled syncarpous cup-shaped fleshy ovary and each carpel has two ovules arranged on an axile placentation (Fig. 1n). The ovary has a $3.3 \pm 0.2 \mathrm{~cm}$ long slender tyle terminated with five broader elongated stigmas which are fused and longitudinally grooved; the ovary is green while the style and stigmas are yellow (Figs. 1i and lm). 


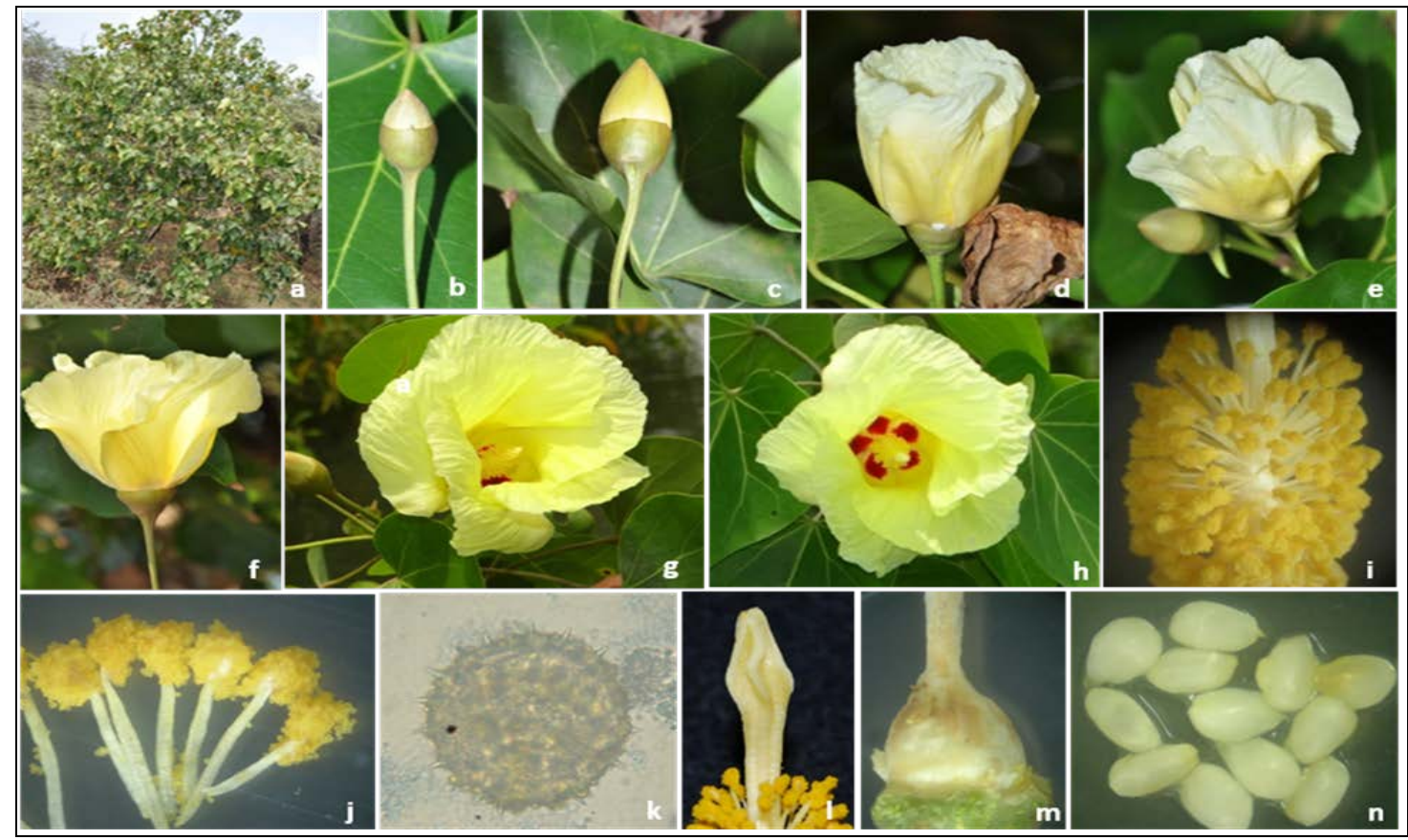

Figure 1: Thespesia populnea a. Habit, b-h. Bud to anthesis stages,

i. Staminal column with style and stigma, j. Stamens with dehisced anthers, k. Pollen grain, l. Style and stigma, m. Ovary, n. Ovules.

Mature buds open early in the morning during 07:00-08:00 h. The process of anthesis takes 30-40 minutes to expose the sex organs (Figs. 1b-h). The flowers are protandrous with anther dehiscence occurring during mature bud stage (Fig. 1j). Individual flowers produce copious pollen. The pollen grains are yellow, sticky, spheroidal, pantoporate, and exine echinate (Fig. 1k). They are herkogamous with spatial separation of sex organs with anthers positioned well below the height of the stigmas. The stigma is wet and attains receptivity an hour after anthesis while it also ceases receptivity coinciding with the initiation of flower closure process. The nectar is secreted in minute volume which varies from $1.2 \pm 0.7 \mu \mathrm{L}$ per flower; its sugar concentration varies from 29 to $35 \%$. The corolla colour which is yellow initially, turns light red between 11:00-12:30 and purplish-pink by early evening (16:00-17:00 h); it closes back enclosing the entire sexual apparatus by late evening hours (17:30-18:30 h) (Figs. 3a-d) and fall off either on 2nd or 3rd day.
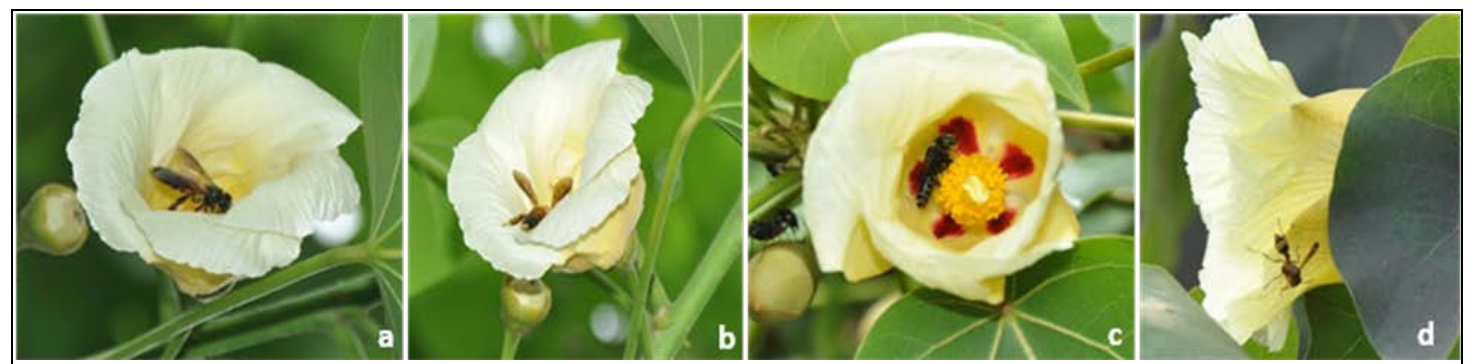

Figure 2: Thespesia populnea, a. and b. Apis dorsata collecting pollen, c. Nomia sp. collecting nectar, d. Polistes sp. leaving the flower after nectar collection. 


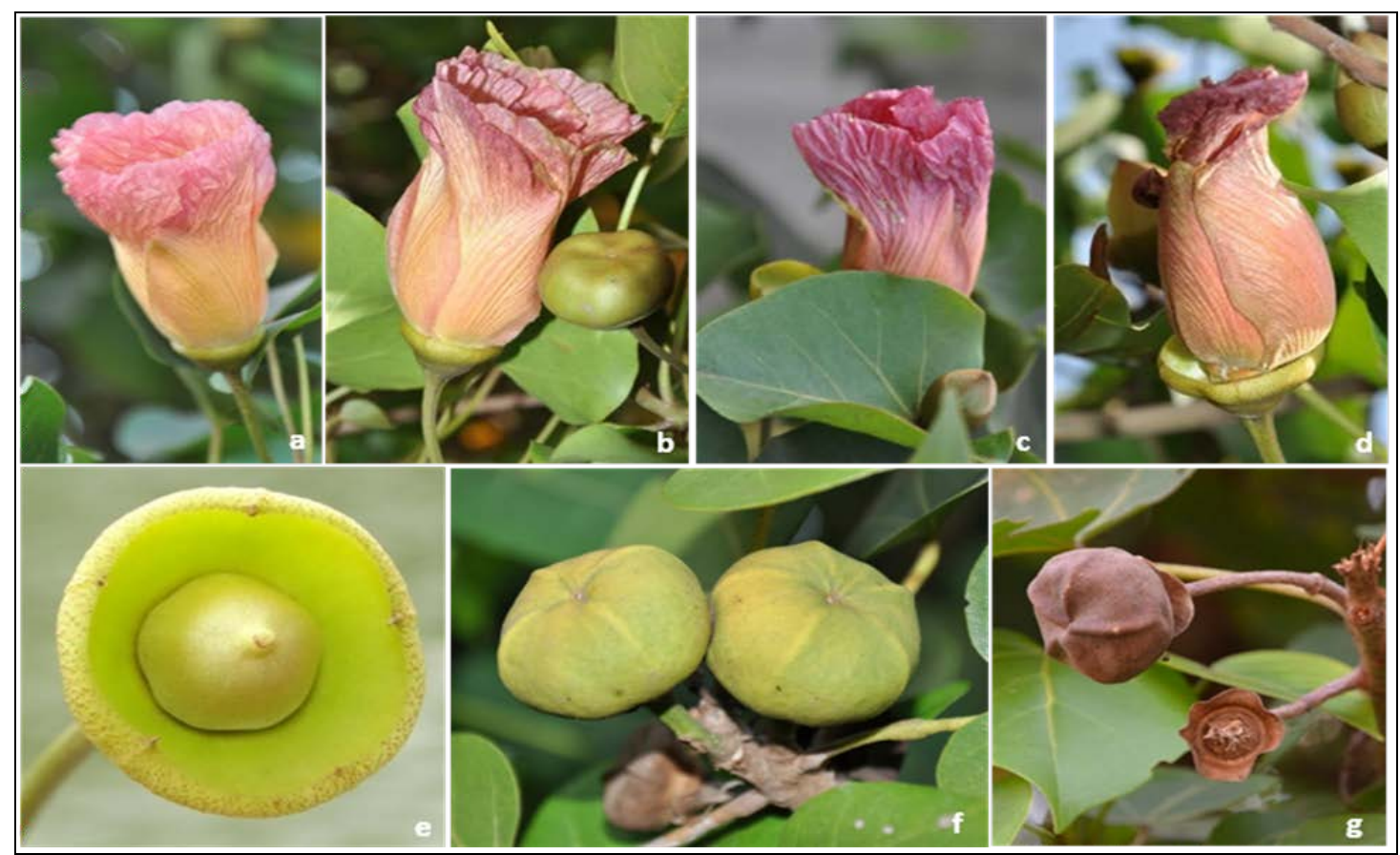

Figure 3: Thespesia populnea, a-d. Gradual flower closure towards evening of the day of anthesis accompanied by corolla colour change from yellow to orange,

e. Growing fruit, f. Maturing fruit, g. Mature dry fruit.

\section{Pollinators}

The fresh bright-yellow flowers in erect position or partially horizontal position are attractive to foraging insects. The flowers were visited by insect species only, they visited during daytime from 08:00 to 16:00 h. The insects included only four bee species, namely Apis dorsata Fabricius 1793 (Figs. 2a-b), A. cerana Fabricius 1793, A. florea Fabricius 1787 and Nomia sp. Latrielle 1804 (Fig. 2c) and one wasp species, Polistes sp. Latrielle 1802 (Fig. 2d). The bees foraged for both nectar and pollen, while the wasp foraged for nectar only. There was no competition among species for the floral rewards. Individual species foraging visits for the day were 118 for A. dorsata, 111 for A. cerana, 124 for A. florea, 100 for Nomia sp. and 97 for Polistes sp. The foraging activity of both bees and wasps was highest during 11:00-13:00 h. The bees approached the flowers in upright position, landed on the corolla and proceeded to collect either pollen or nectar, but not both in the same foraging visit. In case of nectar collection, after landing on the corolla, they directly proceeded to the corolla base for nectar collection by contacting or not contacting the sexual apparatus. After nectar collection, they departed from the flower by walking on the corolla with or without contacting the anthers. The nectar-collection visit was found to be enabling the bees to carry pollen on their ventral side with or without effecting pollination. In case of pollen collection, after landing on the corolla, bees proceeded towards the sexual apparatus, contacted the stigma first and then walked on the staminal column to collect pollen, enabling them to carry pollen on their ventral side. Occasionally, the bees directly landed on the stigmas effecting pollination (if they had pollen of previously visited flowers on their ventral side) and then walked on the staminal column to collect pollen. After pollen collection, they departed from the flower by walking on the corolla. 
The pollen-collection visit was found to be effecting cross-pollination only. The wasp also approached the flowers in upright position, landed on the corolla and proceeded towards the corolla base with or without contacting the anthers to collect nectar. After nectar collection, it moved along the staminal column and the stigmas effecting pollination, and then left the flower. Occasionally, it directly landed on the stigmas and walked on the staminal column to reach the corolla base for nectar collection; in this case, if the wasp had pollen of the previously visited flowers on its ventral side, it would effect cross-pollination. After nectar collection, it moved to the corolla and left the flower. At about the time of initiation of flower closing process, the stigmas gradually reflex backwards and contact the upper level of anthers; the stigmatic movements was found to be a mechanism to facilitate autonomous autogamy in the event of the failure of vector-mediated pollination.

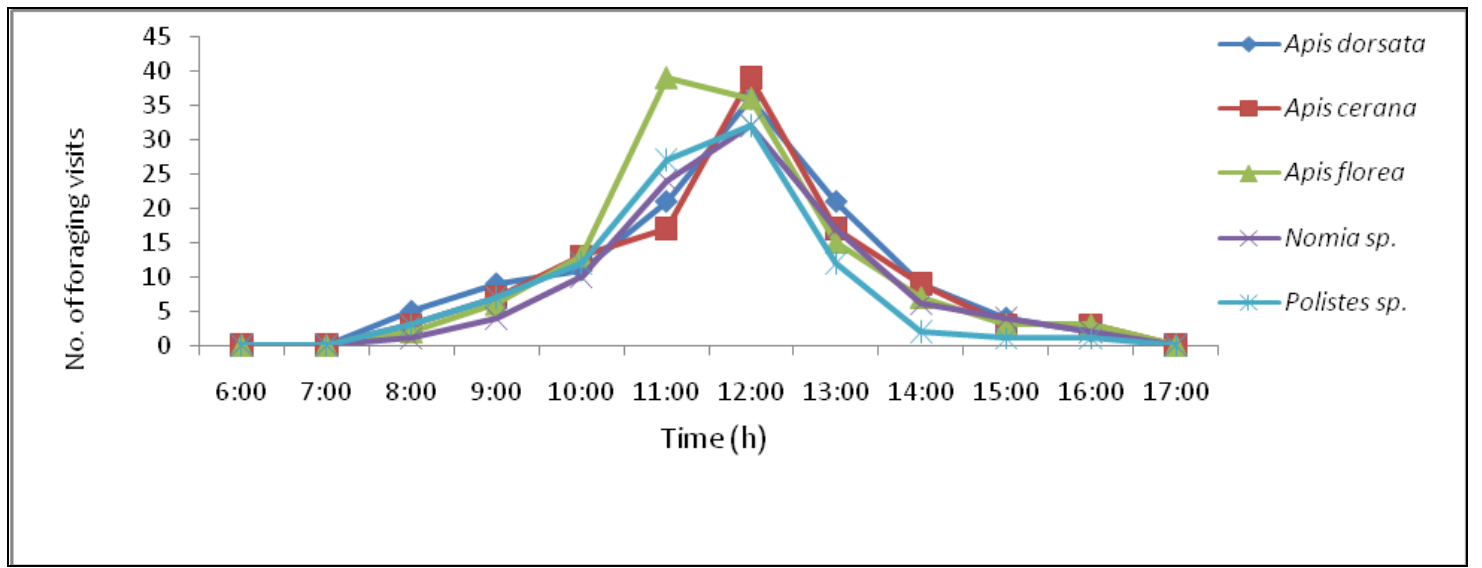

Figure 4: Hourly foraging activity of insects on Thespesia populnea.

\section{Fruiting aspects}

Fruits mature within four-five weeks. They are initially green and brown when mature and dry (Figs. 3e-g). They are five-celled globose, turban-shaped. Indehiscent, capsules, flattened, light weight and woody with disc-like persistent calyx at the base. Individual fruits produce four-10 triangular-ovoid, $10 \pm 1.5 \mathrm{~mm}$ long, brown hairy, veined seeds. Each fruit with seeds inside detach when dry but the persistent calyx remained attached to the plant.

\section{Dispersal aspects}

Fruit is the primary organ of dispersal and it is not dispersed by wind and animals. Fruits and seeds are buoyant but seeds are released by the decay of the capsule in sea water.

\section{DISCUSSION}

\section{Floral biology}

The present study reports that in T. populnea, flowering and fruiting is seasonal, but sporadic flowering and fruiting occurs at other times of the year. This tree species is often confused with Hibiscus tiliaceus because both species have heart-shaped leaves and produce yellow bell-shaped flowers with dark maroon spots at the base of corolla. T. populnea can be easily distinguished by its large yellow bell-shaped flowers, yellow stigmas, rounded and flatten brown turban-shaped capsules. In H. tiliaceus, the flowers are large, yellow, bell- or cup-shaped with maroon coloured base inside the corolla, red stigmas, and ellipsoid loculicidal capsule (Little and Skolmen, 1989). The present study shows that T. populnea with bright yellow flowers against the background of green foliage are attractive even from a long 
distance. The flowers open early in the morning, produce minute volume of nectar and copious pollen, but they close back at the end of the day by which time their corolla colour turns from yellow to purplish-pink. This flower function indicates that the plant keeps its flowers for open-pollination for only one day to facilitate the occurrence of vector-mediated pollination. The stigmatic movements during the process of flower closure appear to be an evolved mechanism to facilitate the occurrence of autonomous autogamy to enable the plant to produce fruits. This mechanism also indicates that the plant is self-compatible and self-pollinating which is further substantiated by the exposure of sex organs by the plant to open-pollination for only one day.

\section{Pollinators}

The foragers of $T$. populnea include bees and wasps, the former collects both nectar and pollen while the latter only nectar. In case of bee foragers, they effect either self- or crosspollination while collecting nectar but the occurrence of either of these pollination modes is related to the contact of the bee with the staminal column and stigmas indicating that each visit made by them for nectar collection does not effect pollination. The bees effect crosspollination while collecting pollen. It is interesting to mention that bees do not collect both nectar and pollen in the same foraging visit to any given flower. The wasp is also important as pollinator because it is instrumental in effecting self- or cross-pollination while collecting nectar. Since nectar is produced in minute volume by individual flowers, this plant mainly serves as copious pollen source for bee foragers. The corolla colour change and retention of flowers for 2nd and 3rd day after their closure appear to be evolved traits to enhance attraction of flowers to insect foragers; these features might have evolved as a compensation for the production of a few flowers daily at plant level. Nevertheless, $T$. populnea is entomophilous in general and melittophilous in particular because bees are the principal pollinators.

\section{Fruiting and seed dispersal}

Kader and Chacko (2000) reported that T. populnea produces one-11 seeds per fruit while fertile seeds vary from three to five per fruit. In this study, it is found that $T$. populnea produces ten ovules per flower and individual fruits produce four-10 seeds. Tomlinson (1989) and Oudhia (2007) noted that T. populnea produces indehiscent fruits and disperse without shedding seeds which are leased only when fruit pericarp decays. The present study substantiates the report by Tomlinson (1989). Different authors mentioned that fruits and seeds of $T$. populnea float in tidal water and adapted for long distance dispersal by tides and ocean currents (Tomlinson, 1989; Kader and Chack, 2000; Friday and Okano, 2006). Further, Friday and Okano (2006) noted that T. populnea seeds remain viable for 24 months in tidal water while Oudhia (2007) mentioned that $T$. populnea seeds tolerate salt water and remain viable even after a year spent in water. Areces-Berazain and Ackerman (2016) noted that T. populnea is hydrochorous. The present study finds that in T. populnea, the fruits and seeds are buoyant because they are light in weight and also have air sacs. Further, saline tidal water has no effect on seed viability since they are viable even after spending more than a year as reported by Friday and Okano (2006) and Oudhia (2007). Therefore, T. populnea is hydrochorous.

The importance of $T$. populnea for various uses has been reported by different authors (Little and Skolmen, 1989; Friday and Okano, 2006; Oudhia, 2007). This study found that it can be used for coastal eco-restoration, cultivated as an ornamental tree species in urban ecosystems and gardens. Further, this tree species can also be raised as a plantation crop in ecologically degraded, damaged, and destroyed coastal areas for carbon sequestration and use its various parts for economic and medicinal purposes. 


\section{CONCLUSIONS}

Thespesia populnea is an evergreen tree species which flourishes well in the coastal areas. It is a seasonal bloomer but blooms sporadically throughout the year. The flowers are hermaphroditic, nectariferous, self-compatible, self-pollinating and entomophilous but largely melittophilous. It is a prolific pollen producer and honey bees use this tree as a major pollen source during its blooming season. The flowers expose the sex organs for open-pollination for only one-day, change colour from yellow to light-red to purplish pink, close back after that, and remain in place for two more days to enhance attraction to the pollinator insects. The fruits are indehiscent capsules which release seeds upon decay of their pericarp in tidal water. Fruit and seed dispersal is hydrochorous. 


\section{ACKNOWLEDGEMENTS}

We thank the Andhra University, Visakhapatnam, for providing all physical facilities to carry out the research work. 


\section{REFERENCES}

1. Areces-Berazain F. and Ackerman J. D., 2016 - Phylogenetics, delimitation and historical biogeography of the pantropical tree genus Thespesia (Malvaceae, Gossypieae), Botanical Journal of the Linnean Society, 181, 171-198.

2. Curtean-Bănăduc A., Schneider-Binder E. and Bănăduc Doru, 2014 - The importance of the riverine ligneous vegetation for the Danube Basin lotic ecosystems, in Cianfaglione K. (ed.), L'importanza degli Alberi e del Bosco, Cultura, scienza e coscienza del territorio, Temi Edit., Trento, Italia, ISBN: 978-88-973772-63-9, I-II, 187-210.

3. Fosberg F. R. and Sachet M. H., 1972 - Thespesia populnea (L.) Solander ex Carrea and Thespesia populneoides (Roxburgh), Kosteletsky (Malvaceae), Smithsonian Contributions to Botany, 7, 13.

4. Francis J. K., 2004 - Thespesia populnea (L.) Sol. ex Carrea, International Institute of Tropical Forestry, USDA, 764.

5. Friday J. B. and Okano D., 2006 - Thespesia populnea (milo), species profiles for Pacific Island Agroforestry, Hawaii, USA, 19.

6. Gandhi T., 2000 - Birds and plant regeneration, Orient Blackswan Pvt. Ltd, Hyderabad, 81.

7. González-Zurdo P., Escudero, A., Babiano J., García-Ciudad A. and Mediavilla S., 2016 Costs of leaf reinforcement in response to winter cold in evergreen species, Tree Physiology, 36, 273-286.

8. Kader S. A. and Chacko K. C., 2000 - Seeds characteristics and germination of portia tree (Thespesia populnea (Linn.) Soland ex Correa), Indian Journal of Forestry, 23, 428-432.

9. Little E. R. Jr. and Skolmen R. G., 1989 - Common forest trees of Hawaii, USDA Agriculture Handbook No. 679, United States Department of Agriculture, Washington DC, USA, 321.

10. Lowman M. D., 2009 - Biodiversity in tropical forest canopies as a "hook" for science education outreach and conservation, Journal of Tropical Ecology, 50, 125-136.

11. Oudhia P., 2007 - Thespesia populnea (L.) Sol. ex Correa, Record from PROTA4U, Louppe D., Oteng-Amoako A. A. and Brink M. (eds), Plant Resources of Tropical Africa (PROTA), Wageningen, Netherlands.

12. Shanmugapriya C. and Vanitharani, J., 2015 - Ecosystem services of lepidoptera to the floral diversity of Mandapam group of islands, The Scitech Journal, 2, 34-40.

13. Singh S. and Kar R., 2011 - Melissopalynological studies on mangrove honeys from Sunderbans (Bangladesh) and Little Andaman (India), Current Science, 100, 1290-1293.

14. Tomlinson P. B., 1986 - The Botany of Mangroves, Cambridge University Press, New York, 419.

15. Troup R. S., 1921 - The Silviculture of Indian Trees, 1, Controller of Publications, Delhi, 300.

16. USDA-ARS, 2015 - Germplasm Resources Information Network (GRIN), Online Database, Beltsville, maryland, USA, National Germplasm Resources Laboratory, https://npgsweb.arsgrin.gov/gringlobal/taxon/taxonomysearch.aspx

17. Van Ommen Kloeke A. E. E., Douma J. C., Ordoñez J. C., Reich P. B. and Bodegom P. M., 2012 - Global quantification of contrasting leaf life span strategies for deciduous and evergreen species in response to environmental conditions, Global Ecology and Biogeography, 21, 224-235.

18. Woodell S. R. J., 1979 - The role of unspecialized pollinators in the reproductive success of Aldabran plants, Philosophical Transactions of Royal Society of London, B, 286, 99-108. 